\title{
PROPAGAÇÃO VEGETATIVA DA GUABIROBEIRA (Campomanesia xanthocarpa BERG.) IN VITRO E POR ESTAQUIA
}

\section{GUABIROBEIRA (Campomanesia xanthocarpa BERG.)VEGETATIVE PROPAGATION IN VITRO AND BY CUTTING}

\author{
Marcia BRUNNER SCUTTI \\ Orientador: Professor Dr. Flavio ZANETTE \\ Departamento de Fitotecnia e Fitossanitarismo
}

\begin{abstract}
RESUMO
A guabirobeira (Campomanesia xanthocarpa Berg.) é uma Mirtácea frutífera lenhosa nativa da região Sul do Brasil, cuja exploração comercial pode ser fomentada por estudos sobre sua propagação vegetativa. Foram empregadas diversas técnicas de propagação vegetativa com o objetivo de estudar o comportamento da espécie. O trabalho está dividido em duas fases: estaquia e micropropagação. Para a estaquia semi-lenhosa foram testados 2 tipos de substrato (100\% Plantmax $₫ ; 2 / 3$ Plantmax ${ }^{\circledR}+1 / 3$ areia) e 7 tratamentos (água; ETANOL 50\%; ETANOL 20\%; ETANOL 40\%; AIB 500 mg.L-1; AIB 1.000 mg.L-1; AIB 2.000 mg.L-1). Para a estaquia herbácea foram testados 6 tratamentos (testemunha, água; ETANOL 50\%; AIB 1.000 mg.L-1; AIB 5.000 mg.L-1; AIB 10.000 mg.L-1) e 2 tempos de imersão ( 30 s e 2 h). Não houve formação de raízes em nenhum dos experimentos. $\mathrm{Na}$ micropropagação a fonte de explantes foram plantas em casa de vegetação e plantas adultas a campo. Em todos os experimentos a desinfestação foi baseada em etanol e $\mathrm{NaOCl}$ comercial e o meio de cultura foi o MS. Os experimentos com micro-estacas de campo ou casa de vegetação não passaram da fase de desinfestação, devido à contaminação bacteriana endógena. $\mathrm{A}$ micro-estaquia de plântulas assépticas utilizou explantes de sementes germinadas in vitro a partir de sementes retiradas de frutos maduros ou iniciando a maturação. A desinfestação foi

realizada sobre os frutos ou sobre as sementes já separadas da polpa e ambas as formas foram eficientes. O teste de multiplicação mostrou que o meio sem reguladores de crescimento apresentou brotações mais longas, enquanto o meio acrescido de 0,5 mg.L-1 de BAP apresentou maior número de brotações por estaca. Houve formação de raiz em meio sem reguladores de crescimento. Na cultura de meristemas foram utilizados meristemas apicais e axilares. Os resultados demonstraram ser possível a eliminação da contaminação bacteriana, mas não houve desenvolvimento $e$ multiplicação dos meristemas. A embriogênese somática foi induzida sobre embriões zigóticos desenvolvidos, retirados de frutos em fase inicial de maturação. Foram realizados testes com diversas combinações de reguladores de crescimento (2,4-D, ANA, $\mathrm{AIB}, \mathrm{BAP}$ e $2 \mathrm{i}-\mathrm{P}$ ) em várias concentrações, visando otimizar as fases da embriogênese, da indução à conversão. Na fase de indução a formação de embriões somáticos ocorreu nos meios com 0,5 a 1 mg.L-1 2,4-D. As fases seguintes mostraram que é possível a diminuição ou retirada do regulador de crescimento, o que estimula 0 ciclo repetitivo e permite o desenvolvimento e conversão dos embriões somáticos. Foi observada a formação de embriões somáticos de forma indireta e direta. Houve conversão de embriões somáticos em plântulas e várias passaram para a aclimatização.
\end{abstract}

\section{ABSTRACT}

The guabirobeira (Canvpomanesia xanthocarpa Berg.) is a native woody fruitful Myrtacea of the South region of Brazil whose commercial exploration can be fomented by studies about its vegetative propagation. Several techniques of vegetative propagation were used with the objective of studying the behavior of the species. The work is divided in two phases: cutting and micropropagation. For the semi-woody cutting 2 substratum types were tested $(100 \%$ Plantmax $\AA 2 / 3$ Plantamax $\AA+1 / 3$ sand $)$ and 7 treatments (water; ethanol $50 \%$; ethanol $20 \%$; ethanol $40 \%$; IBA

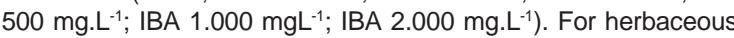
cutting 6 treatments were tested (control, water; ethanol $50 \%$; IBA, $1.000 \mathrm{mg} \cdot \mathrm{LL}^{-1} ;$ IBA $5.000 \mathrm{mg} \cdot \mathrm{L}^{-1}$; IBA $10.000 \mathrm{mg} \cdot \mathrm{L}^{1}$ ) and 2 times of immersion ( $30 \mathrm{~s}$ and $2 \mathrm{hs}$ ). there was no formation of roots in none of the experiments. In the micropropagation, the explants source were plants in green house and adult plants from, the field. In all the experiments the desinfesting was based on ethanol and commercial $\mathrm{NaOCl}$ and the culture medium was the MS. The experiments with field or green house microcuttings didn't pass of desinfesting plisse, due to the bacterial endogenous contamination. The microcuttings of aseptic plantlets used explants of in vitro germinated seeds from mature fruits or fruits beginning the maturation. The desinfestation was accomplished on fruits or on seeds already separated from the pulp and both forms were efficient. The multiplication test showed that the medium without growth regulators presented longer budding, while the medium with $0,5 \mathrm{mg} \cdot \mathrm{L}^{-1}$ of BAP presented larger budding number by cutting. There was root formation in the medium without growth regulators. In the meristems culture, apical and axillary meristems were used. The results demonstrated to be possible the elimination of the bacterial contamination, but there were no development and multiplication of the meristems. The somatic embryogenesis was induced on developed zigotic embryos, removed from fruits in the initial phase of maturation. Tests were accomplished with several combinations of growth regulators (2,4-D, ANA IRA, BAP and 21$P$ ) in several concentrations, seeking optimizing the phases of the embryogenesis, from induction to the conversion. In the induction phase the formation of somatic embryos occured in flue medium with 0,5 to $1 \mathrm{mg} \cdot \mathrm{L}^{-1} 2,4-\mathrm{D}$. The following phases showed that is possible to decrease or retreat the growth regulator, what stimulates the repetitive cycle and allows the development and conversion of the somatic embryos. The formation of somatic embryos in an indirect and direct way was observed. There was conversion of somatic embryos in plantlets and several passed to the climate adaptation, phase in green house. 